\title{
UDC 930.2
}

\section{RETHINKING UKRAINE THROUGH MODERN AMERICAN CINEMATOGRAPH}

\begin{abstract}
Nakashydze I.S.
$P h D$

ORCID: 0000-0002-7816-2339

Radkevich T.O.

PhD, assistant professor ORCID: 0000-0002-8507-7087

Dnipro National University of railway transport named after academician V. Lazaryan,

Dnipro, Lazaryana, 2, 49010

Abstract. 20th and beginning of 21st century are very hard and tragic for Ukrainian people. Until obtaining independence Ukraine was known as part of Soviet Union and many other countries there had been no distinction between Ukraine and Russia. Events in contemporary history (e.g. Orange revolution and Revolution of Dignity) are so large-scale that attracted attention from abroad and made the major part of the world learn about Ukraine and Ukrainians. One of the methods of visualization of these events is films made in cooperation between Ukrainian and American film-makers. North American films try to give foreigners an analysis of Ukrainians' national regeneration through violence in its contemporary history. The aim of this paper is to examine how the image of Ukraine was redefined by American (US and Canadian) cinematographers after the last historical events (Revolution of Dignity and Russian occupation). Majority of these films are documentary, but there are also many artistic works, that help to understand Ukrainian mentality, soul and history.
\end{abstract}

Key words: films, Ukraine, national regeneration, contemporary history.

Introduction. Ukraine is rather young country with interesting and tragic history. Until 1991 it was known as part of Soviet Union and for the majority of the world there had been no distinction between Ukraine or other Soviet republics and Russia. Ivan Katchanovski upon analysis of 100 American films (mainly of 20th century) concluded, that in them"“Russia' and 'Russians' often refer not only to the actual Russia and Russians, but also to other post-Soviet countries, including Ukraine" (Katchanovski 2007). So, if to speak about Ukraine and Ukrainians in American films, they had been shown rarely and as Russians. For example, in Hollywood movie "Taras Bulba" (1962) Ukrainian Cossacks are represented as defenders of the Ukrainian lands and Europe from the Muslim Ottoman Empire, but with Russian traditions.

After obtaining independence in 1991 Ukraine attracted attention of the world political and society, including film-makers. For instance, in "Police Story 4: First Strike" (1996) Jackie Chan follows the Ukrainian Natasha Rushinsky in Ukraine; in "Transporter 3" (2008) one of the heroines is Ukrainian girl Valentina. "Chernobyl Diaries" (2012) is a horror film about six tourists in the abandoned city Pripyat (the former home to the workers of the Chernobyl nuclear reactor) discovers that they are not alone.

Oksana Melnyk depicted main topics of Ukraine in Hollywood films:

- end of the world begins in Ukraine ("Transformers: Dark of the Moon", "War of the Worlds");

- mafia nest ("Lord of War", "Transporter 3"); 
- emigrant life ("Eastern Promises");

- good place for good people ("Eastern Promises", "House of Flying Daggers") (Melnyk 2015).

At the beginning of the 21 st century different TV-shows has become very popular. And in many of them appear Ukraine or Ukrainian people. For instance, in 8 season of "House M.D." (2011) appears Dominika Petrova - Ukrainian emigrant who became fictitious wife of the main hero to obtain US citizenship. In one of the episodes even a portrait of Taras Shevchenko hangs in House's apartment. In "Sex and the City" (2000) Miranda's housemaid is also from Ukraine. She has an image of a religious, caring and excessive woman. In 3 season of "Mr. Robot" (2017) Tyrell Wellick wants himself and his family sent to safety in Ukraine after Stage 2.

Ukrainian enthusiasts in 2014 made a video "56 years, 89 films and one story about Ukraine". It is a research film that consists entirely of US movies scenes where Ukraine or anything Ukrainian is mentioned since 1961. The main purpose of this video is to show what Ukrainian image was made answer the question: "Maybe it is just the right time to rethink Ukraine?" (Vimeo 2014).

The aim of this paper is to examine how the image of Ukraine was redefined by American (US and Canadian) cinematographers after the last historical events (Revolution of Dignity and Russian occupation).

Main text. Events in Ukrainian contemporary history are so large-scale that attracted attention from abroad. First attempt to rethink Ukraine was after so called Orange Revolution in 2004 that was a massive demonstration of Ukrainians for democracy and against electoral fraud. This event lies in the plot of documentary film "The Orange Chronicles" (2017) by Damian Kolodiy and Peter Zielyk. The film explored what motivated the people to activate, as well as the emotional conflicts among a bitterly divided populace. Directors wanted to show how Ukrainians have changed the perception during and after revolution. Though it was not traditional revolution, it is regarded as one of the most important chapter in Ukraine's modern history.

Ukraine became known worldwide during the Euromaidan Revolution (or Revolution of Dignity). In winter 2013-2014 Ukraine was in the main world news, because there were events that were of international importance. These events were followed by Russia's annexation of Crimea and a Russia-instigated war in Donbas. World community continues to open or reopen Ukraine.

One of the methods of visualization of these events and tell about them is films, often made in cooperation between Ukrainian and American moviemakers. For example, film by American director Ben Moses "I am a Ukrainian: personal stories of a revolution" (2014) tells about the Revolution of Dignity and subsequent events in Ukraine through the fate of two characters: Yulia Marushevska - an idealistic graduate student and Andriy Shevchenko - a former TV journalist and opposition member of parliament. On the one hand, the Ben Moses' film is very personal; on the other it forms the idea of the Maidan as a historical phenomenon, provides a powerful back and explanation of the course of events, and therefore is an example of media product, which promotes the proper understanding of the processes inside Ukraine to a foreign viewer. During the Revolution, Ben also made famous clip "I am a 
Ukrainian", which brought the idea of Maidan to a foreign audience.

"Maidan Massacre" (2014) by John Beck Hofmann is an investigative documentary into the shootings which occurred on February 20th, 2014, when nearly 50 people were gunned down on the streets of Kiev's Independence square. Film investigates the scene of the crime, interviewing those who were there when the shootings occurred. This film has received a grand prix of audience sympathy at the 18th International Film Festival 18 Terra di Siena Film Festival in Siena, Italy.

"Winter on Fire: Ukraine's Fight for Freedom" (2015) by American director of Russian decent - Evgeny Afineevsky - is a documentary film about the Euromaidan protests in Ukraine, a co-production of Ukraine, the United States, and the United Kingdom. It tells how peaceful student demonstrations became a violent revolution and full-fledged civil rights movement in Ukraine. Ken Guidry compares this film with "The Square" (2013) which centred on the ongoing crisis happening in Egypt. He says, that to watch "Winter on Fire" is to watch a revolution in progress. "This is a documentary that reminds you of the resiliency of the human spirit" (Guidry 2015).

"Breaking point: the war for democracy in Ukraine" (2016) by Mark Jonathan Harris and Oles Sanin is a view of the war and revolution in Ukraine through the eyes of the simple participants in these events. The main characters are a children's theater director, a doctor, a rabbi, a TV journalist, an investigative reporter, and a lawyer turned medic. Their lives were transformed by the revolution on the Maidan, which ended in the death of 123 protestors and the flight of Viktor Yanukovych. Film shows a struggle that has taken away more than 10 thousand Ukrainians, and millions have ruined their homes. The outcome affects not only the future of Ukraine, but the future of democracy throughout the world.

"Recovery room" (2017) by Adriana Luhovy is a documentary story of hope, resilience and compassion in a time of war in Ukraine. This film tells the story of humanitarian Canadian Medical Mission to Ukraine. 25 Canadian health professionals arrive at the Main Military Clinical Hospital in Kyiv during 2014-2015. There along with Ukrainian volunteers they try to make a difference in the lives of wounded Ukrainian soldiers, first of all by performing complex surgical procedures.

"Julia Blue" (2018) by Roxy Toporowych depicts Ukraine and her people in the post-Maidan era. It is the first American Independent narrative feature film that entirely shot in Ukraine with all Ukrainian cast and crew. Film is about a young woman who comes into her own in a war-torn Ukraine, she finds her path towards independence and a brighter future challenged by an unexpected love. Though "Julia Blue" is only being prepared to world premiere, it is a winner of a prestigious Gotham Award for female film-makers.

It is worth mentioning, that last mentioned events in Ukraine attracted attention not only of American's. Thus, Danish film-maker Simon Lereng produced documentary film "A Distant Barking of Dogs" (2018). It focuses on Donbas region - the front line of Russia's war in Ukraine. The movie follows a 10-year-old Ukrainian boy Oleg for one year to show what it is like to grow up during war. Film received an award for the Best First Appearance at the world's largest documentary film festival International Documentary Film Festival in Amsterdam in November 2017. 
Drama "Frost" (2017) directed by Lithuanian film-maker Šarunas Bartas mixes real events of Russia's war on Ukraine and an artistic plot. It unfolds around a Lithuanian man who travels to the front line in Donbas. There he gets to know war correspondents, falls in love and discovers that the real war is nothing like his romanticized perception of it. The film was premiered at the Cannes Film Festival in May 2017.

Another discovered and reconsidered topic for film-makers is one of the most tragic pages in Ukrainian (and also world) history - Holodomor (1932-1933) - time of forced famine by the Stalin regime. One of the documentary films is "Holodomor: Voices of Survivors" (2015). It is Canadian short documentary film by Ariadna Ochrymovych. The film documents oral history from Ukrainian Canadian survivors of the Holodomor. Rare archival footage, a historical overview and original illustrations complement the interviews. "Ochrymovych said the film is an important piece of world history, one that is relatively unknown and not studied in schools" (Will 2016). Thus this film is essential not only for Ukraine, but for the whole world.

One of the last featured film is Canadian "Bitter Harvest" (2017) by George Mendeluk. Based on one of the biggest tragedies of the 20th century, it is a powerful story of honor, rebellion and survival through the eyes of two young lovers caught in the ravages of Stalin's genocidal policies against Ukraine in the 1930s. Film's subtle message - the Ukrainians will revive their national life, damaged by long history of Russian oppression.

Summary and conclusions. It has been considered that modern North American films try to reopen and rethink Ukraine after two revolutions of the beginning of the 21 st century. They are attempts to give foreigners an analysis of Ukrainians' mentality and national regeneration through violence in its contemporary history. Received results can be deepen in future.

\section{References:}

1. Katchanovski. Ivan. 2007. "Politically Correct Incorrectness: Kazakhstan, Russia, and Ukraine In Hollywood Films." Paper prepared for presentation at the Annual Meeting of the American Political Science Association in Chicago, August 30-September, 2, 2007

2. Melnyk, Oksana. 2015. пронас у зарубіжному кіно [About us in foreign cinema]. UaModna September 11 http://www.uamodna.com/articles/about-us-inforeign-films/

3. Vimeo. 2014. "56 years, 89 titles and a single story about Ukraine". Accessed January 30, 2020 https://vimeo.com/100879777

4. Guidry, Ken. 2015. "Documentary 'Winter on Fire: Ukraine's Fight For Freedom' Is Essential Viewing” Review: of Winter on Fire: Ukraine's Fight For Freedom, October, 7. Indiewire http://www.indiewire.com/2015/10/reviewdocumentary-winter-on-fire-ukraines-fight-for-freedom-is-essential-viewing-113438/

5. Will, Jennifer. 2016. "Holodomor: Voices of Survivors" documentary teaches Regina high school students about genocide. Global News. May 30. Accessed January 29, 2020 https://globalnews.ca/news/2730736/documentary-holodomorvoices-of-survivors-teaches-regina-high-school-students-about-genocide/

Article sent: 25/12/2020

(C) Nakashydze I.S., Radkevich T.O. 